\title{
UN ENIGMÁTICO TÉRMINO CERVANTINO
}

Por

MARCELINO VILLEGAS

En las líneas iniciales de la jornada tercera de Los baños de Argel un Guardián $y$ un Moro comentan:

GUARDIÁN: Los españoles, por su parte, hacen una brava comedia. MORO: Son saetanes, (1) los mismos diablos son; son para todo.

Cervantes traduce la palabra inmediatamente después de usarla (saetanes $=$ diablosl, y no es la única voz árabe, o turca, que así trata el escritor en sus obras de cautivos (2). En todo caso, basta para comprender que saetán es españolización de una palabra árabe, sayțān, y que está usada en plural.

No obstante, los editores de Los baños de Argel cuyo trabajo he consultado, manifiestan un extraño desconcierto ante este término.

El glosario de la edición de Jean Canavaggio (Madrid, Taurus, 1984), que fue la que me llamó la atención sobre saetanes, dice así:

"Término desconocido, a no ser que se trate de una errata" (p. 162).

Florencio Sevilla Arroyo y Antonio Rey Hazas la anotan del siguiente modo en su edición del Teatro completo de Cervantes (Barcelona, Planeta, 1987, p. 252):

(1) Subrayado mío.

(2) En Los baños de Argel: debaí, jornada segunda, verso 309 (1190 del cómputo global). En La gran sultana: xumá (Yum'a), jornada primera verso 62; tarasí, jornada segunda verso 822 (1646 del cómputo globall. En El trato de Argel: nizara (nașārà), jornada cuarta, acotación entre los versos 76 y 77 (2021. 2022 del computo globall. En El gallardo español: Cebrián, jornada primera, acotación entre los versos 316 y 317 
"Así la P. Podría entenderse "satanes". Pero vid. SB, vol. I, p. 379, n. $312: 11 *(3)$

En el volumen y página indicados por F. Sevilla y A. Rey comentan Bonilla y Schevill:

"Así en el texto. Algunos editores han corregido "satanes", vocablo algo extraño en boca de un moro. Si "saetanes" no es errata desconocemos su significado".

Es decir que, entre 1915 y 1987 , la comprensión de esta palabra ha permanecido paralizada. Tanto Jean Canavaggio ("término desconocido, a no ser que se trate de una errata») como F. Sevilla y A. Rey ("podría entenderse satanes") se escudan en la autoridad de Schevill y Bonilla y, sin buscar más horizonte, repiten su inflexible sabiduría: al considerar exclusivamente que Los baños de Argel es una obra de Cervantes les ha impedido ver que es asimismo una obra de ambiente árabe y musulmán; ello es lo que les ha estorbado relacionar eficazmente saetanes y diablos. Salvo que se debiera a razones de época no resulta fácil comprender por qué Schevill y Bonilla eludieron de tal modo el elemento árabe de Los baños de Argel ( "satanes", vocablo algo extraño en boca de un morom), ya que, si es cierto que Satán y Satanás son muy características de la tradición cristiana y bíblica (4), también lo es que no pertenecen exclusivamente a ella: islam y cristianismos son religiones emparentadas; hebreo y árabe son lenguas de un mismo grupo (5).

Es bastante probable que Jean Canavaggio haya perdido la oportunidad de comprender mejor a Cervantes por haber leído las notas de Schevill y Bonilla en vez de Fortune carrée (1929) de Joseph Kessel (1898-1979) (6).

La primera parte de la novela de Kessel transcurre en el Yemen y se titula "Chaïtane", nombre de un pura sangre que el protagonista recibe como regalo al iniciarse el relato. Como en tiempos hiciera Cervantes Joseph Kessel aclara enseguida lo que chaïtane significa:

(3) P. designa la primera edición de Ocho comedias y acho entremeses nuevos, hecha en 1615; SB, la edición en 6 volúmenes de las OC de Cervantes publicada por $R$. Schevill y A. Bonilla entre 1915.

(4) EI DRAE, ediciones de 1956 × 1970, dice de Satán: «(del hebraísmo latino Satán, adversario, enemigo) el demonio, el diablon. Y de Satanás: (del latín Satanas, y éste del hebreo Satann.

(5) Josep M. Solá-Sole no menciona saetanes entre las palabras árabes que estudia en su artículo "Ei árabe y los arabismos en Cervantesn, Sobre árabes, judros y marranos y su impacto en la lengua y la literatura españolas (Barcelona. Puvill libros, 1983, pp. 87/1031. En las pp. $101 / 102$ comenta la frase árabe que aparece en la jornada cuarta de El trato de Argel lacotación entre los versos 98 y 99; 2337-2338 del cómputo globall; su interpretación no excusa la lectura de la que da Mokhtar Abdelouareth en "Revue des Langues” (Úniversidad de Orán), 5 (julio de 1985), pp. 161/163.

(6) Aunque prolífico novelista y miembro de la Academia Francesa desde 1962 hasta la fecha de su muerte, Joseph Kessel es sobre todo natorio por la adaptación que de su novela Belle de jour (1929) hizo Lujs Buñuel en 1966. En 1954 Bernard Borderie realizó una versión cinematográfica poco considerable de Fortune carrée. 
"ll savait aussi le nom de Chaïtane -le diable-que lui avaient donné es palefreniers noirs". ("Sabía también que los palafreneros negros le habían ouesto por nombre Saetán - el diablo-", p. 11).

"Ce démon que. Caitane recélait dans ses flancs, son cavalier le portait aussin ("El demonio que Saetán encubría entre sus flancos también lo llevaba dentro el jinetem, p. 12) (7).

(7) Cito por la edición de Livre de poche (París 1973). 